Supporting Information for

\title{
A Germanium(II)-Centered Dication
}

\author{
Paul A. Rupar, Viktor N. Staroverov, Paul J. Ragogna and Kim. M. Baines \\ Department of Chemistry, University of Western Ontario, London, Ontario, Canada
}

N6A 5B7

kbaines2@uwo.ca

\begin{abstract}
All manipulations were carried out under a dry $\mathrm{N}_{2}$ environment at room temperature in a glove box. Solvents were purified using standard procedures. ${ }^{1} \mathrm{C}_{6} \mathrm{D}_{6}$ was distilled from LAH and $\mathrm{C}_{5} \mathrm{D}_{5} \mathrm{~N}$ was distilled from $\mathrm{CaH}_{2} \cdot \mathrm{GeCl}_{2} \cdot$ dioxane ${ }^{2}$ and $\mathbf{1}^{3}$ were synthesized according to literature procedures. All other chemicals were purchased from commercial sources and used without further purification. NMR chemical shifts are reported in ppm with coupling constants in Hz. ${ }^{1} \mathrm{H}$ NMR spectra were acquired using pyridine- $\mathrm{d}_{5}$ or $\mathrm{C}_{6} \mathrm{D}_{6}$ on an INOVA $400 \mathrm{MHz}$ instrument. ${ }^{1} \mathrm{H}$ NMR spectra were referenced to residual $\mathrm{C}_{6} \mathrm{D}_{5} \mathrm{H}$ (7.15 ppm) or residual pyridine- $\mathrm{d}_{4}(8.71 \mathrm{ppm})$. FT-Raman spectra were collected on a Bruker RFS 100/S. Melting points were determined under a $\mathrm{N}_{2}$ atmosphere and are uncorrected. Elemental analyses were performed at Guelph Chemical Laboratories, Guelph, Ontario, Canada.
\end{abstract}

Synthesis of 2

Carbene 1 (1.0 g, $5.56 \mathrm{mmol})$ was dissolved in $\mathrm{C}_{6} \mathrm{H}_{6}(5 \mathrm{~mL}) . \mathrm{GeCl}_{2} \cdot$ dioxane $(1.28 \mathrm{~g}, 5.56$ mmol) was added directly to the carbene solution. The resulting mixture was clear and colorless. After stirring for $30 \mathrm{~min}$, a white precipitate was observed. Hexanes (10 mL) was then added to the mixture. The precipitate was collected and then washed with 
hexanes $(2 \times 5 \mathrm{~mL})$. The white solid was dried under high vacuum. Yield: $1.54 \mathrm{~g}$ (88\%). M.P. $160-163{ }^{\circ} \mathrm{C}$ (decomposition). ${ }^{1} \mathrm{H}$ NMR: $1.01\left(\mathrm{~d},{ }^{3} J_{H H}=7,12 \mathrm{H}\right), 1.40$ (s, 6 H), 5.58 (broad, 2 H). FT-Raman $\left(\mathrm{cm}^{-1}\right)$ : $111(\mathrm{~m}), 169(\mathrm{~m}), 293(\mathrm{~m}), 316(\mathrm{~s})(\mathrm{Ge}-\mathrm{Cl})$, $529(w), 748(w), 884(w), 1138$ (w), 1434 (w), 1633 (m), 2928 (s), 2981 (s); EI-MS $(\mathrm{m} / \mathrm{z}): 324\left(\mathrm{M}^{+}, 0.4\right)$. High-resolution EI-MS: exact mass calcd for $\mathrm{C}_{11} \mathrm{H}_{20}{ }^{74} \mathrm{GeN}_{2}{ }^{35} \mathrm{Cl}_{2}$ 324.021, found 324.022. Anal. calcd. for $\mathrm{C}_{11} \mathrm{H}_{20} \mathrm{~N}_{2} \mathrm{GeCl}_{2}$ : C, 40.53; $\mathrm{H}, 6.23 ; \mathrm{N}, 8.65$; Found: C, 40.53; H, 6.43; N, 8.91.

Synthesis of $\mathbf{3}$ $2(0.32 \mathrm{~g}, 1 \mathrm{mmol})$ was dissolved in $\mathrm{C}_{6} \mathrm{H}_{6}(5 \mathrm{~mL})$ to give a clear and colorless solution. $\mathrm{Me}_{3} \mathrm{SiI}(0.30 \mathrm{~mL}, 2 \mathrm{mmol})$ was added to the solution. The color of the solution became yellow. The solution was allowed to stir for $1 \mathrm{hr}$, after which a yellow precipitate began to form. Hexanes $(5 \mathrm{~mL})$ was then added to the solution. The yellow precipitate was collected and dried under high vacuum. Yield: $0.35 \mathrm{~g}(69 \%)$. M.P. $162{ }^{\circ} \mathrm{C}$ (decomposition). ${ }^{1} \mathrm{H}$ NMR: $1.14\left(\mathrm{~d},{ }^{3} J_{H H}=7,12 \mathrm{H}\right), 1.45$ (s, $\left.6 \mathrm{H}\right), 5.51$ (broad, $2 \mathrm{H}$ ). FT-Raman $\left(\mathrm{cm}^{-1}\right)$ : 115 (s), 205 (s) (Ge - I), 273 (w), 458 (w), 540 (w), 764 (w), 883 (w), 992 (m), 1282 (m), 1440 (m), 1625 (m), 2936 (m), 2972 (m); EI-MS (m/z): 508 (M+, 0.5), $463\left(\mathrm{M}^{+}-\mathrm{C}_{3} \mathrm{H}_{7}, 10\right), 340\left(\mathrm{M}^{+}-\mathrm{C}_{3} \mathrm{H}_{7} \mathrm{I}, 10\right)$. High-resolution EI-MS: exact mass calcd for $\mathrm{C}_{11} \mathrm{H}_{20}{ }^{72} \mathrm{GeN}_{2} \mathrm{I}_{2}$ 507.893, found 507.893. Anal. calcd. for $\mathrm{C}_{11} \mathrm{H}_{20} \mathrm{~N}_{2} \mathrm{GeI}_{2}: \mathrm{C}$, 26.07; H 3.98; N, 5.53; Found: C, 25.94; H, 3.84; N, 5.73.

Synthesis of $4^{2+} 2 \Gamma^{-}$ 
$3(0.56 \mathrm{~g}, 1.1 \mathrm{mmol})$ was dissolved in THF $(5 \mathrm{~mL})$ to give a yellow solution. Carbene 2 $(0.5 \mathrm{~g}, 2.75 \mathrm{mmol})$ was dissolved in THF ( $3 \mathrm{~mL})$ and then added drop wise to the yellow solution. During addition the yellow color faded and a white precipitate formed. The reaction mixture was stirred vigorously for $18 \mathrm{hr}$. The white precipitate was collected by centrifugation, washed with THF $(2 \times 5 \mathrm{~mL})$ and then dried under high vacuum. Yield: 0.80g (84\%). M. P. $158-162{ }^{\circ} \mathrm{C}$ (decomposition) See Figures $1 \mathrm{~S}-4 \mathrm{~S}$ for ${ }^{1} \mathrm{H}$ NMR spectra. FT-Raman $\left(\mathrm{cm}^{-1}\right): 85$ (m), $304(\mathrm{w}), 694$ (w), 764 (w), 885 (w), 1277 (s), 1349 (m), 1397 (m), 1442 (m), 1621 (m), 2927 (s), 2970 (s); Anal. Calcd. for $\mathrm{C}_{33} \mathrm{H}_{40} \mathrm{~N}_{4} \mathrm{GeI}_{2}$ : C, 40.53; H, 6.23; N, 8.65; Found: C, 40.53; H, 6.43; N, 8.91.

Figure 1S: ${ }^{1} \mathrm{H}$ NMR spectrum of $4^{2+} 2 \mathrm{I}^{-}$at $90{ }^{\circ} \mathrm{C}$ in $\mathrm{C}_{5} \mathrm{D}_{5} \mathrm{~N}$

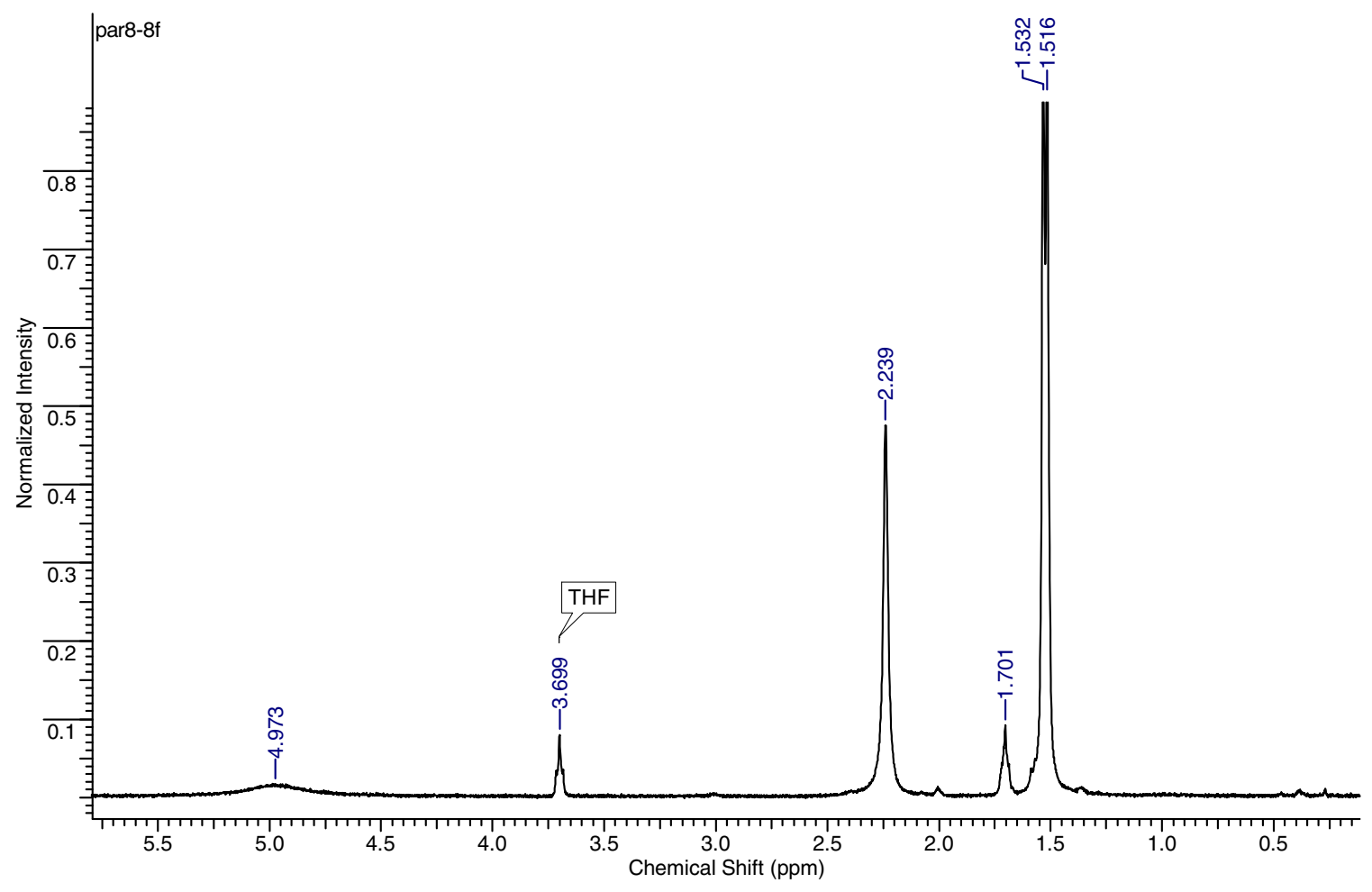


Figure 2S: ${ }^{1} \mathrm{H}$ NMR spectrum of $4{ }^{2+} 2 \mathrm{I}^{-}$at $26^{\circ} \mathrm{C}$ in $\mathrm{C}_{5} \mathrm{D}_{5} \mathrm{~N}$

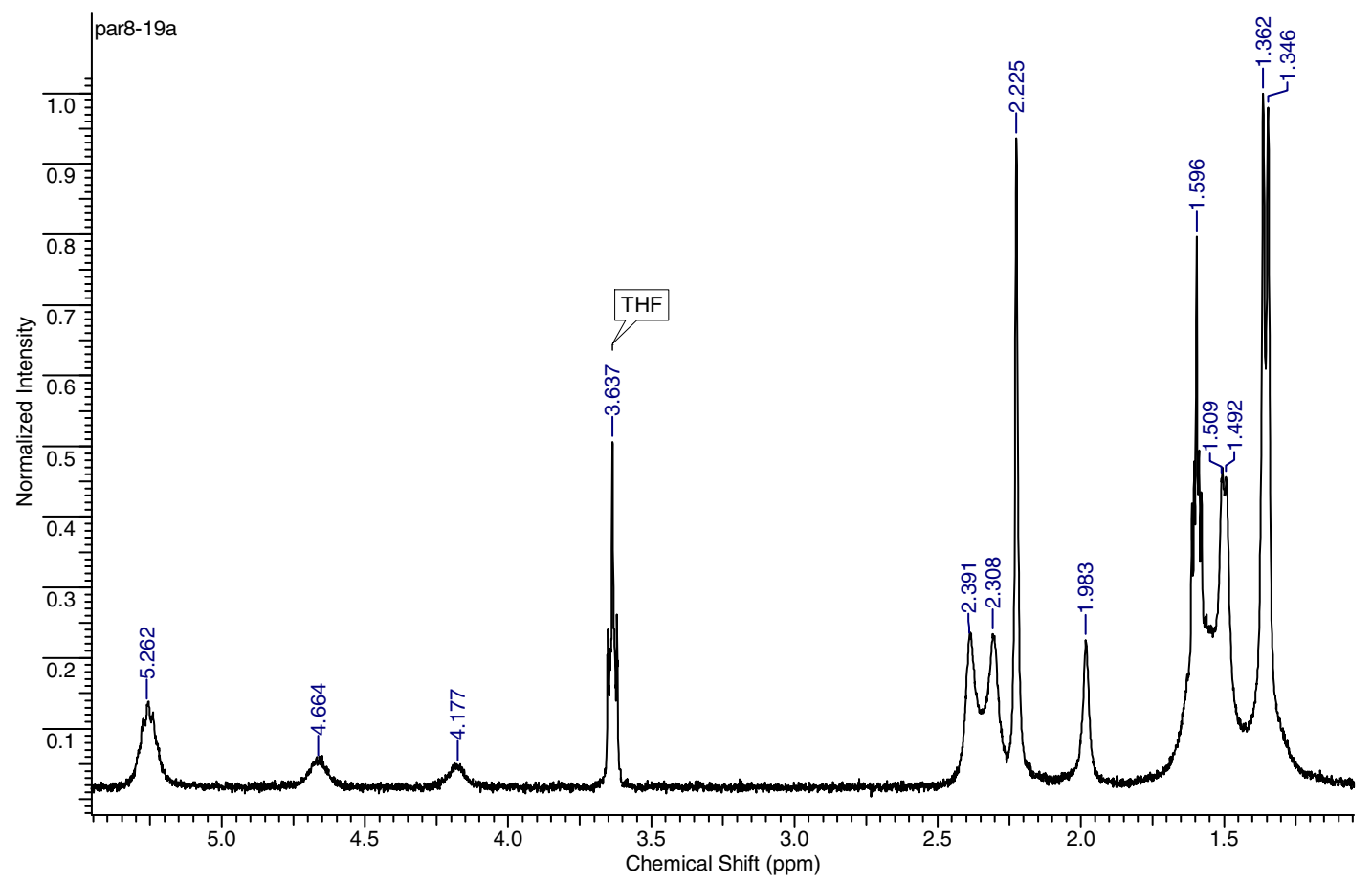

Figure 3S: ${ }^{1} \mathrm{H}$ NMR spectrum of $4^{2+} 2 \mathrm{I}^{-}$at $-20{ }^{\circ} \mathrm{C}$ in $\mathrm{C}_{5} \mathrm{D}_{5} \mathrm{~N}$

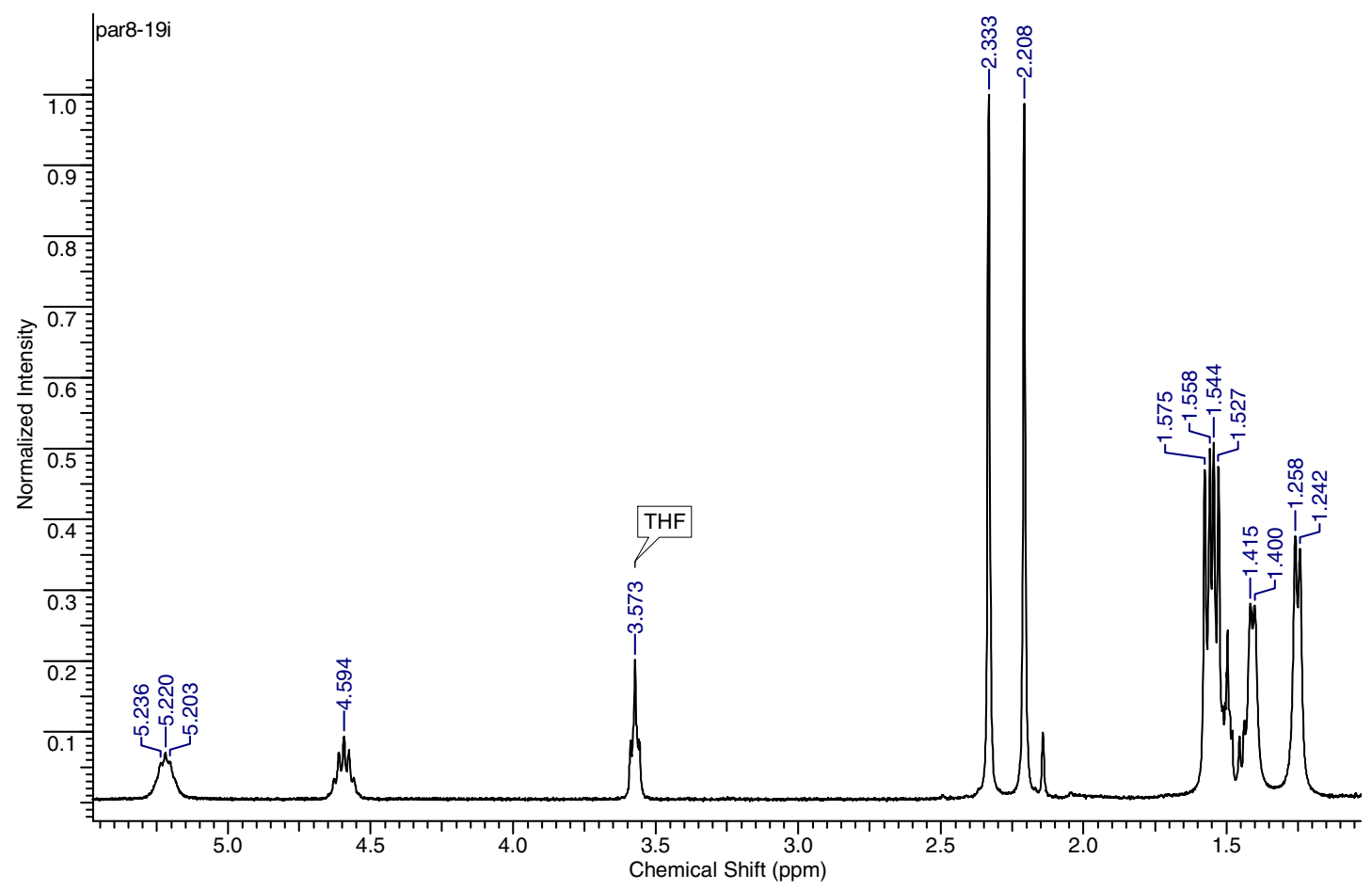


Figure 4S: Expansion of ${ }^{1} \mathrm{H}$ NMR spectrum of $4^{2+} 2 \mathrm{I}^{-}$at $-20{ }^{\circ} \mathrm{C}$ in $\mathrm{C}_{5} \mathrm{D}_{5} \mathrm{~N}$

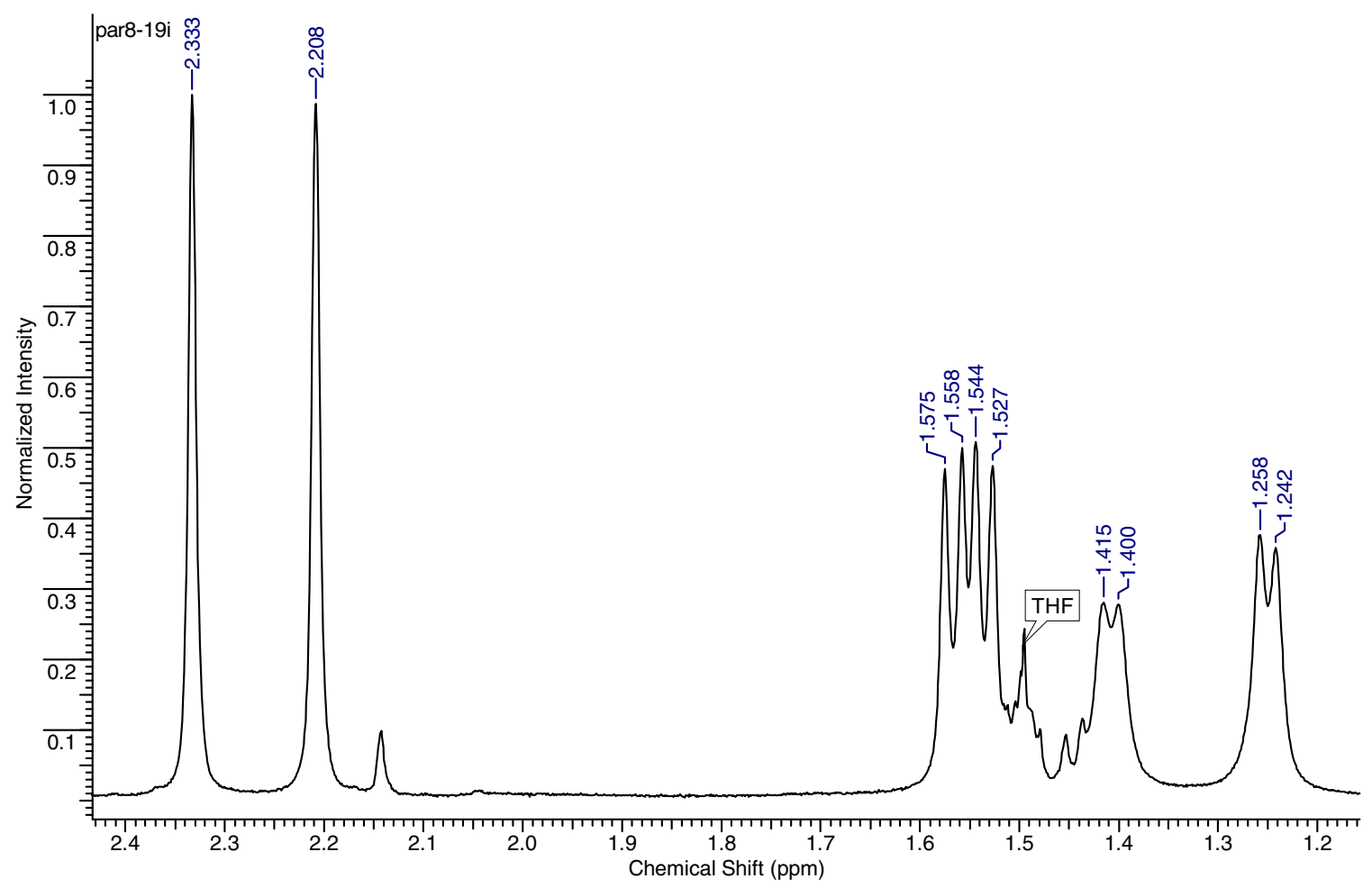




\section{Computational Work:}

Calculations were performed at the B3LYP/6-31G(d) level of theory using Gaussian 03. ${ }^{4}$ The molecular structure of $\mathbf{4}^{2+}$ as determined by X-ray crystallography, with the iodides and pyridine removed, was used as the import coordinates for the geometry optimization. The symmetry of the molecule $\left(\mathrm{C}_{3}\right)$ was maintained during the geometry optimization. Vibrational frequency analysis confirmed that the optimized geometry is an energy minimum. A supplementary text file within the supporting information contains the commands issued to Gaussian 03 for the calculations. Also included within the text file are the coordinates for the initial guess and output for the geometry optimization.

Table 1S: A Comparison of selected experimental and calculated bond lengths and angles for $\mathbf{4}^{2+}$.

\begin{tabular}{|l|l|l|}
\hline & Experimental & B3LYP/6-31G(d) \\
\hline $\mathrm{C} 1-\mathrm{Ge}$ & $2.070(6) \AA$ & $2.0695 \AA$ \\
\hline $\mathrm{N} 2-\mathrm{C} 1$ & $1.319(9) \AA$ & $1.3245 \AA$ \\
\hline $\mathrm{N} 5-\mathrm{C} 1$ & $1.358(9) \AA$ & $1.3445 \AA$ \\
\hline $\mathrm{N} 2-\mathrm{C} 1-\mathrm{N} 5$ & $106.5(6)^{\circ}$ & $107.6^{\circ}$ \\
\hline $\mathrm{C} 1-\mathrm{Ge}-\mathrm{C} 1$ & $103.1(2)^{\circ}$ & $104.0^{\circ}$ \\
\hline
\end{tabular}

Table 2S: Selected atomic charges of $\mathbf{4}^{2+}$ using different population analysis techniques.

\begin{tabular}{|l|l|l|l|}
\hline & Mulliken & NPA & APT \\
\hline $\mathrm{Ge}$ & 0.049860 & 0.63654 & 1.019321 \\
\hline $\mathrm{C}(1)$ & 0.337761 & 0.06648 & -0.051392 \\
\hline $\mathrm{N}(2)$ & -0.493500 & -0.36017 & -0.347381 \\
\hline $\mathrm{C}(3)$ & 0.276817 & 0.16759 & 0.019234 \\
\hline $\mathrm{C}(4)$ & 0.281455 & 0.15964 & 0.057212 \\
\hline $\mathrm{N}(5)$ & -0.482904 & -0.36005 & -0.338967 \\
\hline
\end{tabular}




\section{X-ray Experimentation:}

Thermal Ellipsoid Plots for $\mathbf{2}$ and 3:

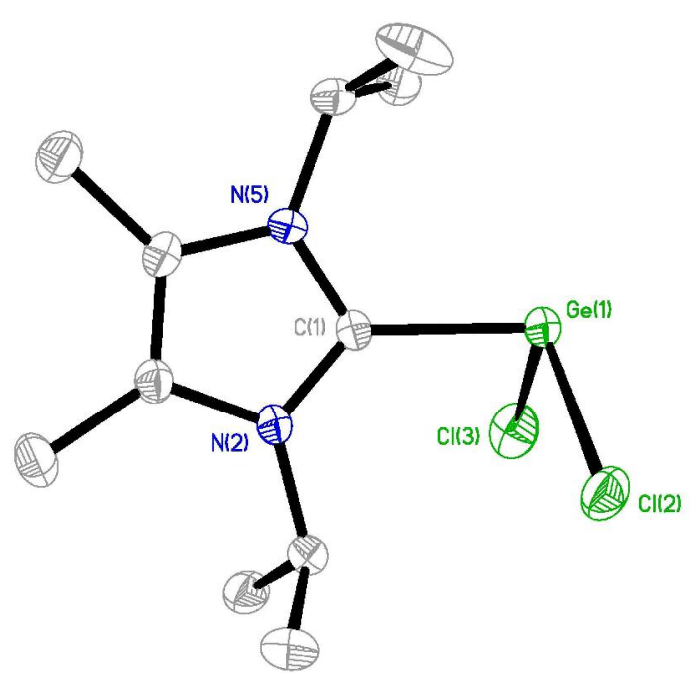

Figure 5S: Thermal ellipsoid plot (50\% probability) for 2. Hydrogen atoms are omitted for clarity. Selected bond lengths $(\AA)$ and angles: $\mathrm{Ge}-\mathrm{C}(1)=2.106(3), \mathrm{Ge}-\mathrm{Cl}(1)=$ 2.2927(9), $\mathrm{Ge}-\mathrm{Cl}(2)=2.2953(8), \mathrm{C}(1)-\mathrm{Ge}-\mathrm{Cl}(1)=93.74(8), \mathrm{C}(1)-\mathrm{Ge}-\mathrm{Cl}(2)=95.74(8)$, $\mathrm{Cl}(1)-\mathrm{Ge}-\mathrm{Cl}(2)=97.82(3)$ 


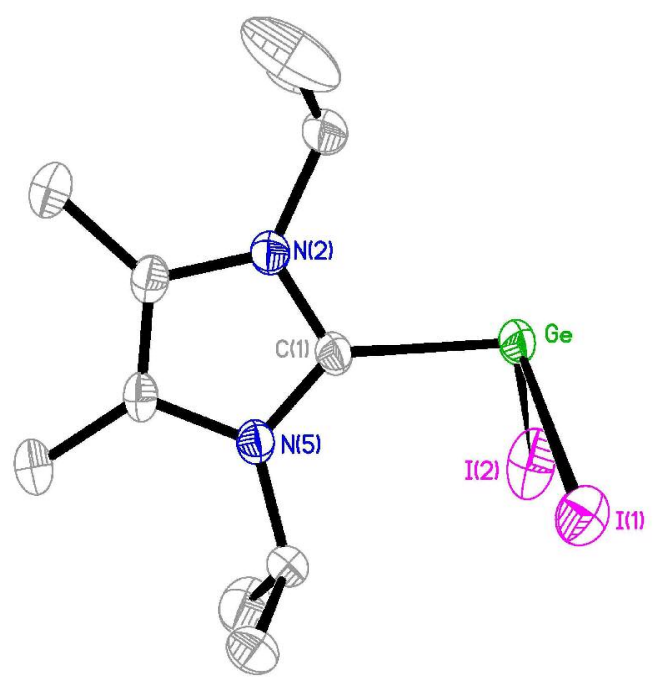

Figure 6S: Thermal ellipsoid plot (50\% probability) for 3. Hydrogen atoms are omitted for clarity. Selected bond lengths $(\AA)$ and angles $\left(^{\circ}\right)$ : C $(1)-\mathrm{Ge}=2.087(3), \mathrm{Ge}-\mathrm{I}(1)=$ 2.6578(5), Ge-I(2) = 2.6863(7), C(1)-Ge-I(1) = 97.07(9), C(1)-Ge-I(2) = 97.93(11), I(1)$\operatorname{Ge}-\mathrm{I}(2)=99.865(17)$ 

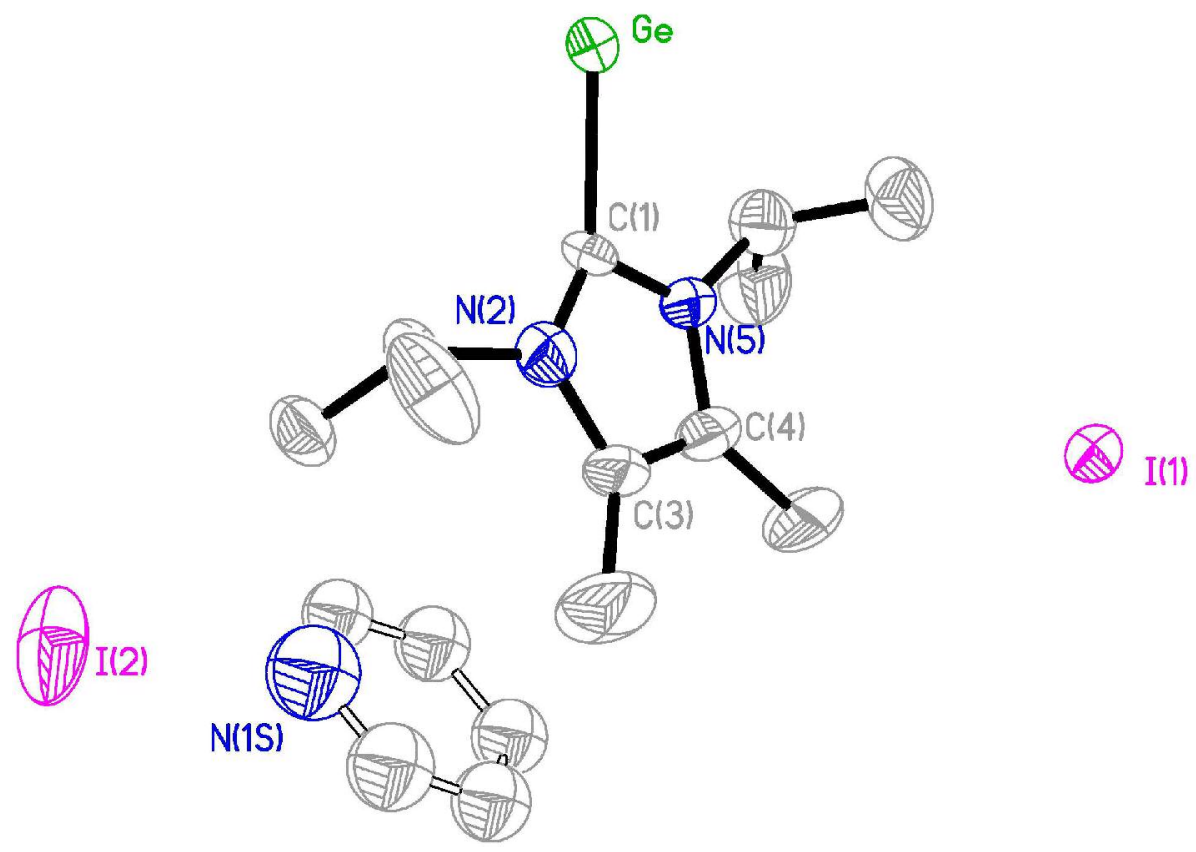

Figure 7S: Thermal ellipsoid plot (50\% probability) of the asymmetric unit of $\mathbf{4}^{2+}$ including pyridine and iodides

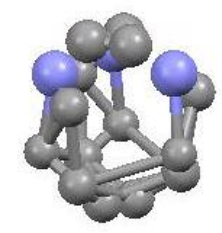

0

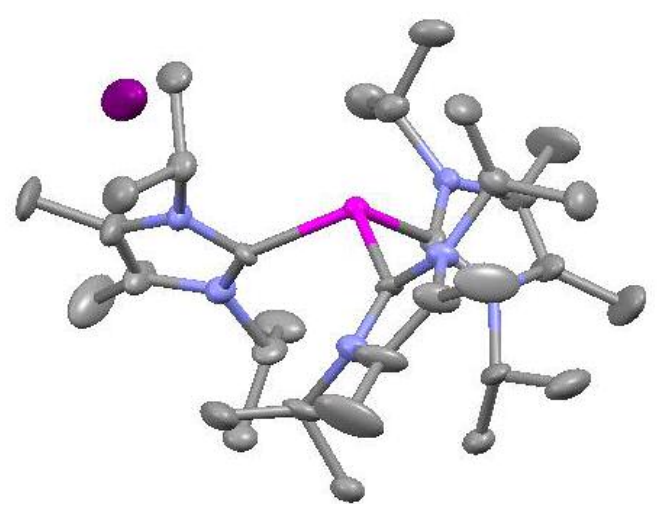

Figure 8S: Thermal ellipsoid plot (30\% probability) of $\mathbf{4}^{2+}$, including pyridine and iodides. 


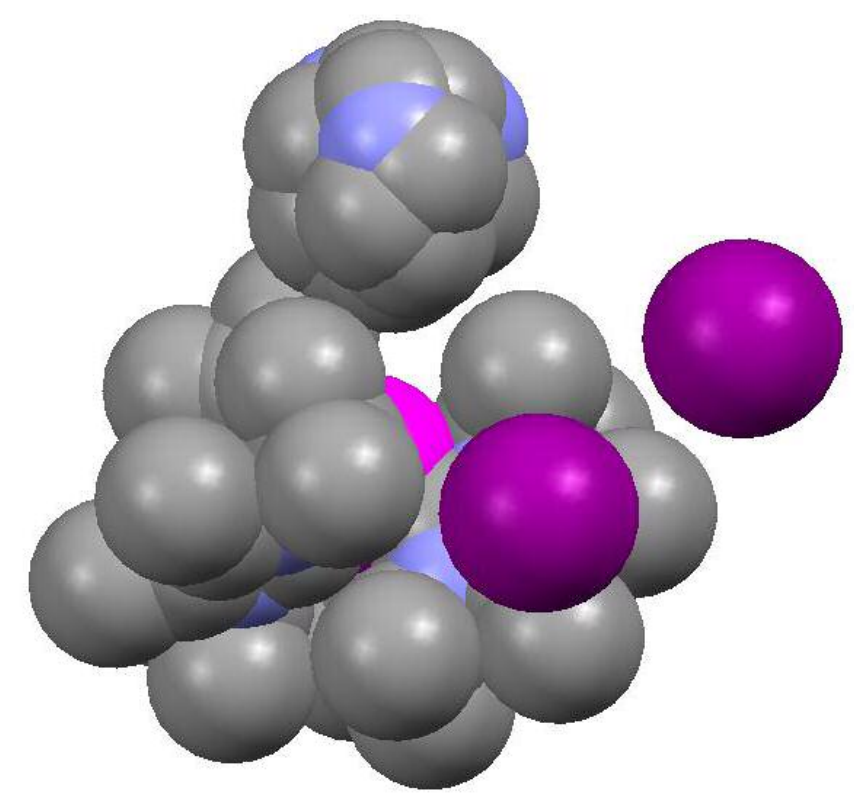

Figure 9S: Space filling model for $\mathbf{4}^{2+}$ including pyridine and iodides

\section{Compound 2}

Crystals of $\mathbf{2}$ were grown by vapor diffusion of diethyl ether into a concentrated benzene solution at room temperature. A colorless plate was coated in heavy paraffin oil and mounted on a nylon loop.

Data were collected at low temperature $\left(-123^{\circ} \mathrm{C}\right)$ on a Nonius Kappa-CCD area detector diffractometer with COLLECT (Nonius B.V., 1997-2002). The unit cell parameters were calculated and refined from the full data set. Crystal cell refinement and data reduction were carried out using HKL2000 DENZO-SMN. ${ }^{5}$ The absorption correction was applied using HKL2000 DENZO-SMN (SCALEPACK). The crystal data and refinement 
parameters are listed in Table S3. The reflection data and systematic absences were consistent with a monoclinic space group: Cc.

The SHELXTL/PC V6.14 for Windows NT (Sheldrick, G.M., 2001) suite of programs was used to solve the structure by direct methods. Subsequent difference Fourier syntheses allowed the remaining atoms to be located. The molecule was a discrete unit and well resolved. All of the non-hydrogen atoms were refined with anisotropic thermal parameters. The hydrogen atom positions were calculated geometrically and were included as riding on their respective carbon atoms.

Full-matrix least squares refinement on $\mathrm{F}^{2}$ gave $\mathrm{R}_{1}=2.91$ for $2 \sigma$ data and $\mathrm{wR}_{2}=7.15$ for all data $(\mathrm{GOOF}=1.031)$. The final solution was submitted to the IUCR checkCIF program and had no Alert Levels A or B.

\section{Compound 3}

Crystals of $3 \cdot\left(\mathrm{C}_{6} \mathrm{H}_{6}\right)$ were grown by vapor diffusion of pentane into a concentrated benzene solution at room temperature. A yellow crystal was coated in paraffin oil and mounted on a nylon loop.

Data were collected at low temperature $\left(-123^{\circ} \mathrm{C}\right)$ on a Nonius Kappa-CCD area detector diffractometer with COLLECT (Nonius B.V., 1997-2002). The unit cell parameters were calculated and refined from the full data set. Crystal cell refinement and data reduction 
were carried out using HKL2000 DENZO-SMN. ${ }^{5}$ The absorption correction was applied using HKL2000 DENZO-SMN (SCALEPACK). The crystal data and refinement parameters are listed in Table S3. The reflection data and systematic absences were consistent with a monoclinic space group: $\mathrm{C} 2 / \mathrm{c}$.

The SHELXTL/PC V6.14 for Windows NT (Sheldrick, G.M., 2001) suite of programs was used to solve the structure by direct methods. Subsequent difference Fourier syntheses allowed the remaining atoms to be located. The molecule was a discrete unit and well resolved. All of the non-hydrogen atoms were refined with anisotropic thermal parameters. The hydrogen atom positions were calculated geometrically and were included as riding on their respective carbon atoms.

Full-matrix least squares refinement on $\mathrm{F}^{2}$ gave $\mathrm{R}_{1}=3.54$ for $2 \sigma$ data and $\mathrm{wR}_{2}=9.26$ for all data $(\mathrm{GOOF}=1.061)$. The final solution was submitted to the IUCR checkCIF program and had no Alert Levels A or B.

\section{Compound $4^{2+} 2 \mathrm{I}^{-}$}

Crystals of $4^{2+} 2 \mathrm{I}^{-} \cdot\left(\mathrm{C}_{5} \mathrm{H}_{5} \mathrm{~N}\right)$ were grown by vapor diffusion of diethyl ether into a concentrated pyridine solution at room temperature. A colorless crystal was coated in paraffin oil and mounted on a nylon loop. 
Data were collected at low temperature $\left(-123^{\circ} \mathrm{C}\right)$ on a Nonius Kappa-CCD area detector diffractometer with COLLECT (Nonius B.V., 1997-2002). The unit cell parameters were calculated and refined from the full data set. Crystal cell refinement and data reduction were carried out using HKL2000 DENZO-SMN. ${ }^{5}$ The absorption correction was applied using HKL2000 DENZO-SMN (SCALEPACK). The crystal data and refinement parameters are listed in Table S3. The reflection data and systematic absences were consistent with a cubic space group: $\mathrm{P} 2{ }_{1} 3$.

The SHELXTL/PC V6.14 for Windows NT (Sheldrick, G.M., 2001) suite of programs was used to solve the structure by direct methods. Subsequent difference Fourier syntheses allowed the remaining atoms to be located. Only one carbene fragment is in the asymmetric unit. The remaining two carbenes are generated via three fold axis of symmetry on which the germanium lies. I(2) was located very close to, but not directly upon a three axis and was disordered. This disorder was modeled by with three iodides at 1/3 occupancy. A molecule of pyridine was located upon a three fold axis and was also disordered. The pyridine was modeled by placing an idealized pyridine molecule at the observed position and refining as a rigid group. Site symmetry was suppressed for the pyridine (part $-1 \ldots$ part 0 in Shelxl). A total of three molecules of pyridine are generated by symmetry each at $1 / 3$ occupancy. All of the non-hydrogen atoms were refined with anisotropic thermal parameters with the exception of the pyridine molecule which was left isotropic. The hydrogen atom positions were calculated geometrically and were included as riding on their respective carbon atoms. 
The thermal ellipsoids of the carbene fragment are rather large; especially so for C6 and C7. All of the thermal ellipsoids of the central atoms in the carbene fragment are directionalized perpendicular to the plane of the carbene. This trend was also observed in an initial, lower quality data set for $4^{2+} 2 \Gamma^{-}$(not presented in this communication). We believe that the ellipsoids represent some slight disorder of the carbene fragment position due to pivoting at $\mathrm{C} 1$ with regards to the $\mathrm{Ge}-\mathrm{C} 1$ bond. The increasing size of the thermal ellipsoids as the distance from $\mathrm{C} 1$ increases is consistent with this hypothesis.

Full-matrix least squares refinement on $\mathrm{F}^{2}$ gave $\mathrm{R}_{1}=6.32$ for $2 \sigma$ data and $\mathrm{wR}_{2}=14.27$ for all data $(\mathrm{GOOF}=1.199)$. The final solution was submitted to the IUCR checkCIF program and had one Alert level B due to the large thermal ellipsoid.

Table 3S: Crystallographic Data for 2,3 and 4

\begin{tabular}{|c|c|c|c|}
\hline & 2 & 3 . benzene & $\mathbf{4}^{2+} 2 \mathrm{I}^{-} \cdot$ pyridine \\
\hline Empirical formula & $\mathrm{C}_{11} \mathrm{H}_{20} \mathrm{Cl}_{2} \mathrm{GeN}_{2}$ & $\begin{array}{l}\mathrm{C}_{11} \mathrm{H}_{20} \mathrm{~N}_{2} \mathrm{Ge}, \\
0.5\left(\mathrm{C}_{6} \mathrm{H}_{6}\right)\end{array}$ & $\begin{array}{l}\left(\mathrm{C}_{11} \mathrm{H}_{20} \mathrm{~N}_{2}\right)_{3} \mathrm{Ge}, 2 \mathrm{I}, \\
\mathrm{C}_{5} \mathrm{H}_{5} \mathrm{~N}\end{array}$ \\
\hline Formula weight & 323.78 & 545.73 & 946.36 \\
\hline Temperature (K) & \multicolumn{3}{|c|}{150} \\
\hline Wavelength $(\AA)$ & \multicolumn{3}{|c|}{0.71073} \\
\hline Crystal system & Monoclinic & Monoclinic & Cubic \\
\hline Space group & $\mathrm{Cc}$ & $\mathrm{C} 2 / \mathrm{c}$ & $\mathrm{P} 2{ }_{1} 3$ \\
\hline$a(\AA)$ & $14.0114(4)$ & 21.4774(7) & $16.3681(3)$ \\
\hline$b(\AA)$ & $9.3901(3)$ & $8.6709(3)$ & \\
\hline$c(\AA)$ & $11.5641(4)$ & $20.2449(7)$ & \\
\hline$\beta\left(^{\circ}\right)$ & $106.168(2)$ & $100.7940(14)$ & 90 \\
\hline Volume $\left(\AA^{3}\right)$ & $1461.30(8)$ & $3703.5(2)$ & $4385.25(14)$ \\
\hline
\end{tabular}




\begin{tabular}{|c|c|c|c|}
\hline $\mathrm{Z}$ & 4 & 8 & 4 \\
\hline $\begin{array}{l}\text { Calculated density } \\
\left(\mathrm{g} / \mathrm{cm}^{3}\right)\end{array}$ & 1.472 & 1.958 & 1.433 \\
\hline $\begin{array}{l}\text { Absorption coefficient } \\
\left(\mathrm{mm}^{-1}\right)\end{array}$ & 2.440 & 4.980 & 2.139 \\
\hline$F(000)$ & 664 & 2072 & 1920 \\
\hline Crystal size $\left(\mathrm{mm}^{3}\right)$ & $0.48 \times 0.28 \times 0.25$ & $0.45 \times 0.40 \times 0.30$ & $0.14 \times 0.10 \times 0.05$ \\
\hline $\begin{array}{l}\theta \text { range for data collection } \\
\qquad\left({ }^{\circ}\right)\end{array}$ & $2.64-27.49$ & $2.05-27.49$ & $2.16-27.46$ \\
\hline Reflections collected & 8491 & 16561 & 48407 \\
\hline Independent reflections & $\begin{array}{l}3226 \\
{[\text { Rint }=0.066]}\end{array}$ & $\begin{array}{l}4236 \\
{[\text { Rint }=0.056]}\end{array}$ & $\begin{array}{l}3366 \\
{[\text { Rint }=0.088]}\end{array}$ \\
\hline Completeness (\%) & 99.8 & 99.8 & 99.8 \\
\hline Absorption correction & \multicolumn{3}{|c|}{ Semi-empirical from equivalents } \\
\hline Data/restraints/parameters & $3226 / 2 / 152$ & $4236 / 0 / 180$ & $3366 / 0 / 153$ \\
\hline Goodness-of-fit $F^{2}$ & 1.031 & 1.062 & 1.199 \\
\hline Final $\mathrm{R}$ indices $[I>2 \sigma(I)]$ & $\begin{array}{l}\mathrm{R}_{1}=0.0291, w \mathrm{R}_{2} \\
=0.0707\end{array}$ & $\begin{array}{l}\mathrm{R}_{1}=0.0354, w \mathrm{R}_{2} \\
=0.0900\end{array}$ & $\begin{array}{l}\mathrm{R}_{1}=0.0632, w \mathrm{R}_{2}= \\
0.1418\end{array}$ \\
\hline $\mathrm{R}$ indices (all data) & $\begin{array}{l}\mathrm{R}_{1}=0.0300, w \mathrm{R}_{2} \\
=0.0715\end{array}$ & $\begin{array}{l}\mathrm{R}_{1}=0.0402, w \mathrm{R}_{2} \\
=0.0927\end{array}$ & $\begin{array}{l}\mathbf{R}_{1}=0.0652, w \mathbf{R}_{2}= \\
0.1427\end{array}$ \\
\hline $\begin{array}{c}\text { Largest diff. peak and } \\
\text { hole }\left(\mathrm{e} \AA^{-3}\right)\end{array}$ & $\begin{array}{l}0.432 \\
-0.534\end{array}$ & $\begin{array}{l}0.810 \\
-1.405\end{array}$ & $\begin{array}{l}1.661 \\
-0.581\end{array}$ \\
\hline
\end{tabular}

\footnotetext{
${ }^{1}$ Pangborn, A. B.; Giardello, M. A.; Grubbs, R. H.; Rosen, R. K.; Timmers, F. J. Organometallics, 1996, 15,1518

${ }^{2}$ Leigh, W. J.; Harrington, C. R.; Vargas-Baca, I. J. Am. Chem. Soc. 2004, 126, 16105

${ }^{3}$ Kuhn, N; Kratz, T. Synthesis 1993, 561

${ }^{4}$ Gaussian 03, Revision B.05, Frisch, M. J.; Trucks, G. W.; Schlegel, H. B.; Scuseria, G. E.; Robb, M. A.; Cheeseman, J. R.; Montgomery, Jr., J. A.; Vreven, T.; Kudin, K. N.; Burant, J. C.; Millam, J. M.; Iyengar, S. S.; Tomasi, J.; Barone, V.; Mennucci, B.; Cossi, M.; Scalmani, G.; Rega, N.; Petersson, G. A.; Nakatsuji, H.; Hada, M.; Ehara, M.; Toyota, K.; Fukuda, R.; Hasegawa, J.; Ishida, M.; Nakajima, T.; Honda, Y.; Kitao, O.; Nakai, H.; Klene, M.; Li, X.; Knox, J. E.; Hratchian, H. P.; Cross, J. B.; Bakken, V.; Adamo, C.; Jaramillo, J.; Gomperts, R.; Stratmann, R. E.; Yazyev, O.; Austin, A. J.; Cammi, R.; Pomelli, C.; Ochterski, J. W.; Ayala, P. Y.; Morokuma, K.; Voth, G. A.; Salvador, P.; Dannenberg, J. J.; Zakrzewski, V. G.; Dapprich, S.; Daniels, A. D.; Strain, M. C.; Farkas, O.; Malick, D. K.; Rabuck, A. D.; Raghavachari, K.; Foresman, J. B.; Ortiz, J. V.; Cui, Q.; Baboul, A. G.; Clifford, S.; Cioslowski, J.; Stefanov, B. B.; Liu, G.;
} 
Liashenko, A.; Piskorz, P.; Komaromi, I.; Martin, R. L.; Fox, D. J.; Keith, T.; Al-Laham, M. A.; Peng, C. Y.; Nanayakkara, A.; Challacombe, M.; Gill, P. M. W.; Johnson, B.; Chen, W.; Wong, M. W.; Gonzalez, C.; and Pople, J. A.; Gaussian, Inc., Wallingford CT, 2004.

${ }^{5}$ Z. Otwinowski and W. Minor. In Methods in Enzymology. Vol. 276: Macromolecular Crystallography, Part A. Edited by C.W. Carter, Jr. and R.M. Sweet. Academic Press, New York. 1997. p. 307 